Volume 13, Nomor 1, Mei 2021, pp 160-172 Copyright (C 2017

Jurnal Akuntansi, Program Studi Akuntansi, Fakultas Bisnis,



http://journal.maranatha.edu

\title{
Pengaruh Deferred Tax, Capital Intensity, dan Return on Asset terhadap Agresivitas Pajak
}

\author{
Angeline Margaretha ${ }^{1}$ \\ Universitas Advent Indonesia \\ (Jl. Kolonel Masturi No.288, Parongpong, Bandung Barat) \\ 1832018@unai.edu \\ Mila Susanti ${ }^{2}$ \\ Universitas Advent Indonesia \\ (Jl. Kolonel Masturi No.288, Parongpong, Bandung Barat) \\ milasusanti@unai.edu \\ Valentine Siagian $^{3}$ \\ Universitas Advent Indonesia \\ (J1. Kolonel Masturi No.288, Parongpong, Bandung Barat) \\ valentine@unai.edu
}

\begin{abstract}
This research was conducted to identify the effect of Deferred Tax, Capital Intensity, and Return On Assets on Tax Aggressiveness in the coal mining sub-sector industry. This research uses a quantitative descriptive method. This paper uses secondary data from information that was obtained from the coal mining sub-sector listed on the Indonesia Stock Exchange in 2016-2019. The data collection method used purposive sampling. In this paper, there are several analysis used to process the data, which are, descriptive statistic analysis, correlation coefficient analysis, determination coefficient analysis, multiple linear regression analysis, significance test, and classical assumption test assisted by using Statistical Product and Service Solutions (SPSS) 23. The results of this research prove simultaneously. Deferred Tax Asset, Capital Intensity, and Return On Asset have a significant effect on tax aggressiveness, with the resulting significance value $(0.006<0.05)$. However, partially deferred tax assets do not have a significant effect on tax aggressiveness (0.365>0.05), on the other hand, Capital Intensity is significant $(0.001<0.05)$, and Return On Asset has a negative significance $(0.002<0.05)$ effect to tax aggressiveness.
\end{abstract}

Keywords : Deferred Tax Expense, Capital Intensity, Return On Asset, and Tax Aggressiveness 


\begin{abstract}
Abstrak
Penelitian ini dilakukan untuk mengenali pengaruh Deferred Tax, Capital Intensity, serta Return On Asset terhadap Agresivitas Pajak pada industri sub sektor pertambangan batubara. Riset ini memakai tata cara deskriptif kuantitatif. Data sekunder yang digunakan dalam penelitian ini menggunakan informasi industri sub sektor pertambangan batubara yang terdaftar di Bursa Efek Indonesia tahun 2016-2019. Metode pengambilan data memakai purposive sampling. Analisis yang digunakan untuk melakukan pengolahan data adalah statistik deskriptif, analisa koefisien korelasi, analisa koefisien determinasi, analisis regresi linier berganda, uji signifikansi serta uji asumsi klasik yang dibantu dengan Statistical Product and Service Solutions (SPSS) 23. Hasil riset ini membuktikan secara simultan Deferred Tax Asset, Capital Intensity serta Return On Asset mempunyai pengaruh signifikan terhadap agresivitas pajak, dengan hasil nilai signifikansi $(0,006<0,05)$. Namun secara parsial deferred tax asset tidak mempunyai pengaruh signifikan terhadap agresivitas pajak, signifikansi $(0,365>0,05)$, sebaliknya Capital Intensity dengan signifikansi $(0,001<0,05)$, serta Return On Asset yang mempunyai signifikansi $(0,002<0,05)$ mempunyai pengaruh negatif signifikan terhadap agresivitas pajak.
\end{abstract}

\title{
Kata Kunci: Deferred Tax Asset, Capital Intensity, Return On Asset, dan Agresivitas Pajak
}

\section{Pendahuluan}

Sebuah negara dapat berdiri dengan baik dikarenakan lancarnya perputaran ekonomi negara tersebut. Dimana perputaran ekonomi ini dilakukan oleh perusahaan dalam negeri maupun luar negeri. Negara dapat mengambil keuntungan dari setiap kegiatan perusahaan, yang terutama melalui sektor pajak. Menurut undang-undang Nomor. 28 Tahun 2007, Pajak merupakan donasi wajib kepada negeri yang terutang oleh orang individu ataupun badan yang bersifat mendesak bersumber pada undangundang dengan tidak memperoleh imbalan secara langsung serta digunakan kepada keperluan negeri untuk sebesar-besarnya kemakmuran rakyat. Dengan demikian pajak memiliki peranan penting bagi perekonomian Negara. Kemenkeu.go.id yang merupakan situs resmi dari Kementerian Keuangan Republik Indonesia pada tahun 2019 sudah mempublikasikan penerimaan pajak yang terdapat di Anggaran Pemasukan serta Belanja Negara (APBN). Dalam laporan keuangan akhir Desember 2019 tercatat $78,86 \%$ dari jumlah pendapatan negara berasal dari pajak, dan 21,14\% merupakan Pendapatan Negara Bukan Pajak (PNPB)(Kementerian Keuangan, 2019).

Penerimaan atas sektor pajak dapat dikatakan mengalami peningkatan setiap tahunnya tetapi belum terjadi secara konsisten. Hal ini dapat saja terjadi karena ada faktor-faktor yang menghambat, baik dari segi badan ataupun wajib pajak pribadi yang sedang melakukan penghindaran pajak. Agresivitas pajak merupakan strategi yang perusahaan gunakan dalam mengurangi beban pajak. Agresivitas pajak sendiri merupakan kegiatan mengurangi pemasukan kena pajak melalui dua cara, yaitu Tax Avoidance \& Tax Evasion. Menurut Xynas (2011) penghindaran pajak (Tax Avoidance) ialah usaha perusahaan dalam mengurangi beban pajak yang bersifat legal (Lawful) sedangkan penggelapan pajak (Tax Evasion) ialah usaha perusahaan untuk mengecilkan beban pajak yang bersifat tidak legal (Unlawful). Meskipun dalam beberapa hal tidak bertentangan dengan peraturan yang ada, tetapi semakin besar celah penghematan pajak sebuah industri maka industri tersebut 
semakin agresif atas pajak.

Pada kasus yang diberitakan Brama, Global Witness menganalisis penggelapan pajak di salah satu industri tambang batu bara, PT Adaro Energy Tbk. Sejak 2009 hingga 2019, pembayaran pajak perseroan tersebut kepada pemerintah Indonesia turun sebesar US \$ 125 juta. Dilaporkan bahwa metode yang diterapkan oleh perusahaan tersebut adalah transfer pricing. Dengan adanya selisih pajak (tax gap) ketika realisasi penerimaan pajak dapat menjadi salah satu indikasi bahwa wajib pajak melakukan penggelapan pajak (Asroni, Nur, \& Yuyetta, 2019). Karena itu banyak pihak yang memanfaatkan celah atau kelemahan dalam regulasi perpajakan yang ada, dan menjadikan agresivitas pajak menjadi aktivitas yang legal. Perbedaan prinsip penggunaan peraturan perpajakan untuk akuntansi adalah celah, yang dapat digunakan untuk melakukannya penghindaran pajak. Perihal perusahaan melakukan tindakan agresivitas pajak dapat dipengaruhi beberapa faktor seperti halnya profitabilitas, deferred tax, dan capital intensity. Capital intensity ratio dapat diartikan menjadi pengukuran besarnya perusahaan dalam melakukan investasi pada asetnya dalam persediaan dan aset tetap. Perihal aset tetap sebagian besar aset tetap mengalami depresiasi dan biaya daripada depresiasi tersebut dapat memberikan efek jumlah pajak yang akan dibayarkan perusahaan. Menurut Mulyani, Darminto, \& Endang N.P (2014), semakin tingginya aset tetap pada laporan keuangan perusahaan maka pajak yang dibayarkan akan lebih rendah begitu juga sebaliknya. Metode depresiasi yang diizinkan pada peraturan perpajakan hanyalah garis lurus dan saldo menurun. Menurut Hanafi, Mamduh M; Halim (2012), Return on Asset (ROA) ialah bagian dari tanda yang dapat menggambarkan profit di suatu perusahaan. Yang dimana profitabilitas merupakan salah satu penarik perhatian calon pemegang saham dalam suatu perusahaan. Salah satu penanda yang bisa mencerminkan profitabilitas suatu industri. ROA ditampilkan dalam bentuk presentase, semakin besar presentase nilai ROA maka kinerja perusahaan tersebut semakin bermutu. Ketika kinerja perusahan semakin baik maka semakin besar pula beban perusahan tersebut dalam membayar pajak. Deferred tax asset didefinisikan sebagai akumulasi pajak penghasilan yang bisa dikembalikan pada periode berikutnya. Hal ini terjadi karena adanya perbedaan temporer, akumulasi pajak yang belum dikompensasikan dan akumulasi kredit pajak belum digunakan dimana aturan pajak mengizinkannya. Dimana dengan adanya rencana perusahaan dalam menurunkan estimasi pajak perusahaan akan memperoleh laba yang lebih besar, estimasi yang direncanakan perusahaan salah satunya adalah berhubungan dengan pajak tangguhan dalam menentukan liabilitas ataupun aset pajak tangguhan. Didalam hal perpajakan pajak tangguhan sendiri dapat memberikan pengaruh dalam hal mengurangi ataupun menambah beban pajak pada tahun tersebut. Di dalam penelitian Putra (2019) dikatakan bahwa Deferred Tax Asset memiliki pengaruh positif atas manajemen laba. Manajemen laba sendiri merupakan bagian dari faktor yang dapat dilakukan perusahaan dalam melakukan agresivitas pajak, dimana hal tersebut dikuatkan oleh penelitian Feryansyah, Handajani \& Hermanto (2020). Berdasarkan kajian singkat dan perbedaan hasil daripada penelitian terdahulu maka menimbulkan pertanyaan yang dituliskan lewat 4 rumusan masalah dibawah ini:

1. Bagaimana pengaruh Deferred Tax Asset atas agresivitas pajak?

2. Bagaimana pengaruh Capital Intensity atas agresivitas pajak?

3. Bagaimana pengaruh Return on Asset atas agresivitas pajak?

4. Bagaiman pengaruh DTA, CAIN, dan ROA atas agresivitas pajak?

Untuk tujuan daripada dilakukannya riset ini adalah:

1. Menganalisa pengaruh Deferred 
Tax Asset atas agresivitas pajak pada perusahan sub sektor pertambangan batubara.

2. Menganalisa pengaruh Capital Intensity atas agresivitas pajak pada perusahaan sub sektor pertambangan batubara.

3. Menganalisa pengaruh Return on Asset atas agresivitas pajak pada perusahaan sub sektor pertambangan batubara.

4. Menganalisa pengaruh DTA, CAIN, dan ROA atas agresivitas pajak pada perusahaan sub sektor pertambangan batubara.

\section{Kerangka Teoretis dan Hipotesis}

\section{Tinjauan Pustaka}

\section{Deferred Tax}

Deferred Tax pada Pernyataan Standar Akuntansi Keuangan (PSAK) No.46 yang telah di revisi pada tahun 2012 menunjukkan bahwa aset pajak tangguhan ialah besarnya pajak penghasilan yang terpulihkan di masa depan dimana hal ini terjadi akibat dari adanya perbedaan temporer. Diakui nya deferred tax ini memiliki dampak terhadap berkurangnya laba atau liabilitas akibat adanya pengakuan deferred tax expense atau deferred tax asset. Deferred tax expense ialah jumlah DTE yang ada diakibatkan pengukuran atas aset atau kewajiban pajak tangguhan. Menurut Waluyo (2020), aset pajak tangguhan ialah hasil daripada perbedaan waktu dimana mengakibatkan koreksi positif dan hasilnya beban pajak berdasarkan sudut komersial lebih kecil daripada beban pajak dari sudut Undangundang pajak.

Tingkat aset pajak tangguhan termasuk pencatatan apabila adanya realisasi manfaat pajak pada masa depan. Dan oleh sebab itu judgement diperlukan untuk melakukan penaksiran seberapa tingkat DTA itu sendiri dapat terealisasi.

\section{Capital Intensity}

Meningkatnya modal perusahaan bisa dilihat dari penurunan aset tetap (penjualan) atau peningkatan aset tetap (pembelian). Pengukuran kinerja melalui aset tetap, dapat dilakukan dengan pengukuran Capital Intensity. Menurut pandangan Putri \& Lautania (2016), capital intensity ialah pengakumulasian modal perusahaan dimana modal tersebut diinvestasikan kepada aktiva tetap dan rasio ini diukur dengan rasio aktiva tetap berbanding dengan penjualan. Ketika aset tetap suatu perusahaan meningkat maka perusahaan itu akan semakin produktif yang akan menghasilkan laba yang besar. Seringkali capital intensity didefinisikan sebagai gambaran suatu penginvestasian perusahaan dalam bentuk aset tetap. Menurut Sudana (2015), capital intensity bertolak belakang daripada fixed asset turnover ratio. Ditambahkan oleh Rangkuti (2017), rasio capital intensity ini mengukur keefisiensian daripada aset perusahaan dalam menciptakan penjualan. Brigham \& Houston (2014) juga menerangkan dimana rasio ini menjadi tolak ukur keefektifan perusahaan menggunakan peralatannya.

\section{Return On Asset (ROA)}

ROA ialah rasio profitabilitas yang melihat seluruh modal yang dimanfaatkan untuk menghasilkan keuntungan atau dengan kata lain perbandingan laba usaha dengan modal usaha, sehingga tinggi rendah nya laba merupakan penentu keberhasilan suatu perusahaan. Menurut Brigham \& Houston (2014), ROA mengukur kinerja perusahaan dalam menggunakan aset untuk menghasilkan laba bersih terlepas dari bagaimana perusahaan membiayai akuisisi aset tersebut. Sedangkan Rangkuti (2013) mengatakan bahwa ROA mengukur keefektifan manajemen yang dilihat melalui keuntungan yang dihasilkan perusahaan.

Ketika angka pada ROA dan juga profitabilitas cukup tinggi maka akan terjadi 
peningkatan investor yang tertarik dalam menanamkan modal pada perusahaan tersebut. Dengan begitu perusahaan akan selalu mencari celah agar bisa melakukan agresivitas pajak dengan cara meminimalkan pajak yang seharusnya menjadi tanggungan perusahaan, agar dapat mempertahankan keuntungan yang tinggi. Menurut Brigham \& Houston (2014) tingkatan ROA apabila lebih tinggi menunjukkan kondisi lebih baik daripada ROA dibawah rata-rata. Pengembalian atas aset ROA yang rendah boleh terjadi disebabkan penggunaan utang yang besar, yang dalam hal ini beban bunga yang tinggi akan menyebabkan laba neto menjadi rendah. Penggunaan tolak ukur hasil bagi laba bersih setelah pajak berbanding dengan total aset akan menghasilkan nilai pengembalian atas aset total.

\section{Agresivitas Pajak}

Dilihat dari sisi negara, pajak ialah pendapatan terbesar bagi suatu negara tetapi hal ini bertolak belakang dengan sisi perusahaan yang menganggap pajak sebagai beban perusahaan. Maka dari itu timbulah strategi untuk memperkecil pembayaran pajak oleh perusahaan kepada negara dengan cara agresivitas pajak. Sampai saat ini belum didefinisikan secara jelas didalam undang-undang perpajakan Indonesia mengenai pajak agresif, tetapi boleh ditemukan dari hasil beberapa penelitian yang mencoba mengartikan agresivitas pajak. Lanis \& Richardson (2012) menyatakan agresivitas pajak merupakan kegiatan perusahaan dalam merekayasa pendapatan kena pajak melalui perencanaan pajak, dan boleh dilakukan melalui dua cara yaitu secara legal (tax avoidance) ataupun secara ilegal (tax evasion). Lietz (2013) menyatakan agresivitas pajak merupakan strategi pengolahan pajak yang agresif. Strategi pengolahan pajak termasuk agresif apabila tidak secara terang-terangan melanggar peraturan perpajakan yang berlaku dimana nantinya berdampak negatif pada perkembangan perusahaan.
Dari pernyataan-pernyataan diatas peneliti menarik kesimpulan dimana agresivitas pajak dilakukan bukan hanya penghindaran saja, tetapi juga dapat dilakukan melalui penggelapan pajak. Tujuan daripada dilakukannya agresivitas pajak sendiri yaitu untuk meminimalkan pajak yang harus perusahaan bayarkan kepada negara tetapi masih dalam batas wajar. Kegiatan agresivitas pajak ini juga dilakukan berdasarkan tingkat keefektifan pembayaran yang terjadi. Effective Tax Rate (ETR) digunakan dalam pengukuran agresivitas pajak itu sendiri. Beban pajak terhadap laba dapat menggambarkan keefektifan pajak dimana semakin besar persentase ETR maka dapat dikatakan penghindaran pajak yang dilakukan perusahaan semakin rendah dan begitu juga sebaliknya. ETR sendiri dapat menampilkan secara spesifik agresivitas pajak.

\section{Perumusan Hipotesis}

\section{Pengaruh Deferred Tax terhadap Agresivitas Pajak}

Deferred Tax Asset sendiri terjadi pada saat terjadinya perbedaan temporer yang mengakibatkan laba akuntansi lebih besar dibandingkan laba fiskal. Hal ini dapat mendorong industri untuk melakukan penundaan hutang pajak periode mendatang. Maka daripada itu dapat diasumsikan DTA merupakan salah satu indikator adanya agresivitas pajak. Pada penelitian terdahulu yang dilakukan oleh Cahyani \& Kiswara (2019) menuliskan bahwa ratio pajak tangguhan memiliki pengaruh yang signifikan terhadap penghindaran pajak.

$\mathbf{H}_{1}$ : Terdapat pengaruh positif antara Deferred Tax atas agresivitas pajak

\section{Pengaruh Capital Intesity atas Agresivitas Pajak}

Capital intensity biasanya seringkali dihubungkan bersama tingkat aset tetap, juga persediaan dari suatu perusahaan. Aset tetap itu sendiri dapat berpengaruh dengan penurunan beban pajak yang perusahaan 
harus bayarkan dikarenakan depresiasi dari aset tetap itu sendiri. Dimana aset tetap yang perusahaan miliki kedepannya memunculkan beban depresiasi per periodenya sehingga akan menurunkan laba sebelum pajak. Melalui itu dapat dikatakan semakin tinggi aset tetap satu perusahaan maka semakin besar kemungkinan minat perusahaan tersebut agresif tehadap pajak. Hidayat \& Fitria (2018) menuliskan dalam penelitiannya variabel capital intensity berpengaruh signifikan atas agresivitas pajak. Begitupun hal nya dengan penelitian Rahmadi \& Suharti (2018).

$\mathbf{H}_{2}$ : Terdapat pengaruh yang positif antara Capital Intesity atas agresivitas pajak.

\section{Pengaruh Return On Asset atas Agresivitas Pajak}

Return On Asset menampilkan tinggi rendahnya tingkat pengembalian yang dihasilkan daripada setiap rupiah yang ditanamkan yang berbentuk aset (Murhadi, 2015). Maka daripada itu hasil ROA sendiri berperan sebagai tolak ukur dari tingkat aset yang perusahaan miliki. Pada penelitian Rina Adriani, R.,\& Fadillah (2019) menyatakan ROA memiliki pengaruh positif signifikan atas agresivitas pajak, sedangkan hal ini bertolak belakang dengan penelitian Sahala \& Siahaan (2020) yang menyatakan ROA tidak memiliki pengaruh yang signifikan terhadap agresivitas pajak.

H3: Terdapat pengaruh positif signifikan antara Return On Asset atas agresivitas pajak.

Pengaruh Deferred Tax, Capital Intensity dan Return On Asset atas Agresivitas Pajak

Melalui penjelasan-penjelasan sebelumnya dimana DTA berpengaruh terhadap agresivitas pajak melalui pengurangan beban pajak, CAPIN berpengaruh terhadap agresivitas pajak melalui biaya depresiasi yang dapat mengurangi beban pajak, dan ROA yang menunjukkan tingkat kinerja perusahaan sehingga semakin tinggi persentase ROA yang perusahaan miliki semakin besar pula pajak yang dibebankan. Sehingga variabel-variabel tersebut diasumsikan memiliki pengaruh atas agresivitas pajak. Pernyataan-pernyataan sebelumnya juga didukung oleh penelitipeneliti sebelumnya, DTA oleh Cahyani \& Kiswara (2019),CAPIN oleh Hidayat \& Fitria (2018) dan juga ROA oleh Sahala \& Siahaan (2020), diasumsikan berpengaruh terhadap agresivitas pajak maka dari itu peneliti menuliskan hipotesis seperti dibawah ini:

$\mathbf{H}_{4}$ : Terdapat pengaruh yang signifikan diantara Deferred Tax, Capital Intesity dan Return On Asset atas agresivitas pajak

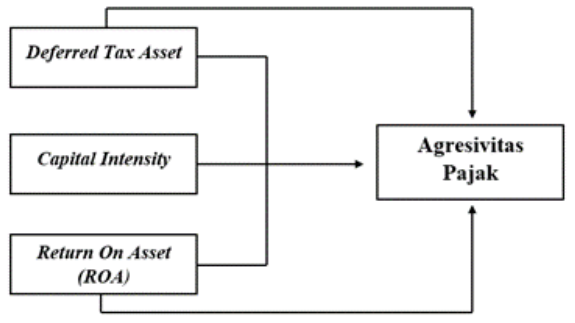

Gambar 1

Kerangka Konsep Penelitian

Sumber: Penulis

\section{Metode Penelitian}

\section{Jenis Data}

Pada riset ini penulis menggunakan data kuantitatif dimana sumber data dalam riset ini merupakan data sekunder.

\section{Definisi Operasional Variabel Penelitian}

\section{Variable Independent $(\mathrm{X})$}

Deferred Tax Asset sendiri dapat diukur dengan menggunakan rumus sebagi berikut:

$$
\text { DTAit }=\frac{\Delta \text { Deferred Tax Asset }}{\text { Deferred Tax Asset }-1}
$$


Capital Intensity Untuk pengukuranya sendiri ialah aset tetap terhadap penjualan. (Wijaya, 2017) .

$$
\text { Capital Intensity }=\frac{\text { Total Aset Tetap }}{\text { Penjualan }}
$$

Return On Asset digunakan dalam mengukur seberapa besar kemampuan aset dalam menghasilkan laba pada perusahaan dengan pengukuran:

$$
\boldsymbol{R} \boldsymbol{O} \boldsymbol{A}=\frac{\text { LABA SETELAH PAJAK }}{\text { TOTAL ASSET }}
$$

Variable Dependent (Y):

Agresivitas Pajak dengan indikator ETR (Effective Tax Rate)

$$
\boldsymbol{E T R}=\frac{\text { Total Beban Pajak Penghasilan }}{\text { Laba Sebelum Pajak }}
$$

\section{Populasi dan Sampel}

Populasi yang dipakai pada riset ini merupakan laporan keuangan dari industri sub sektor pertambangan batubara yang terdaftar di BEI. Dilihat dari besar nya jumlah perusahaan yang terdaftar membuat penulis memiliki ketertarikan dalam menggunakan sektor ini, dan juga didukung dengan fenomena yang terjadi di Indonesia dimana negara sempat kehilangan potensi pendapatan dari sektor tersebut. Untuk sampel yang dipakai adalah laporan keuangan industri sub-sektor pertambangan batubara periode 2016-2019 dikarenakan belum ada penelitian secara spesifik yang dilakukan dengan variabel $\mathrm{x}$ dan $\mathrm{y}$ atas sub sektor pertambangan batubara periode 2016-2019. Pada perusahaan sub sektor batubara tercatat 22 perusahaan. Pada proses pengambilan sampel metode yang digunakan ialah purposive sampling:

166
1. Perusahaan sub sektor pertambangan batubara yang tercatat di BEI periode 2016-2019

2. Perusahaan memiliki laporan keuangan yang memiliki komposisi deferred tax asset, total aset tetap, penjualan, laba setelah pajak, total aset, total beban pajak penghasilan, laba sebelum pajak selama periode 2016-2019.

Berdasarkan ketentuan diatas maka tersaringlah 13 perusahaan yang memenuhi ketentuan sebagai sampel pada penelitian ini. Ke-13 perusahaan tersebut dikali 4 tahun, sehingga menghasilkan 52 total sampel penelitian. Dikarenakan terdapat 14 data outliers maka total sampel tersaring sejumlah 38 sampel penelitian.

\section{Sumber Data}

Sumber data didalam penelitian ini diambil dari situs resmi Bursa Efek Indonesia (BEI) yaitu https://www.idx.co.id/ dalam bentuk annual report perusahaan pertambangan sektor pertambangan batubara dalam periode 2016-2019. Laporan keuangan dari 13 perusahaan pertambangan batubara, dengan kode perusahaan ADRO, BSSR, BUMI, BYAN, DEWA, DOID, GEMS, HRUM, KKGI, MBAP, MYOH, PTBA, TOBA.

\section{Analisis Data}

Untuk uji hipotesis penelitian, digunakan metode analisis dengan menggunakan regresi linear berganda dengan tujuan untuk memperkirakan tentang apa yang bisa jadi terjadi di masa depan berdasarkan informasi yang dihasilkan secara sistematis. Pada riset ini akan menggunakan statistik deskriptif, uji asumsi klasik (uji normalitas, multikolinearitas, dan heteroskedastisitas), uji kelayakan model (uji adjusted $\mathrm{R}^{2}$, uji $\mathrm{F}$, uji t) juga analisis regresi linear berganda dimana persamaan umum yang sering digunakan adalah $\mathrm{Y}=\mathrm{a}+\mathrm{b} 1 \mathrm{X} 1+\mathrm{b} 2 \mathrm{X} 2 \ldots$. + bnXn. (Perdana, 2016). Rumus persamaan umum pada penelitian ini penulis jabarkan sebagai berikut: 
APon $=\alpha 0+\beta 1$ DTon $+\beta 2$ CIon $+\beta 3$ ROAon $+\mathrm{e}$

Keterangan:

$\begin{array}{ll}\text { APon } & \text { :Agresivitas Pajak } \\ & \begin{array}{l}\text { perusahaan i tahun ke-t } \\ \text { menggunakan proksi }\end{array} \\ & \text { ETR. } \\ \alpha 0 & : \text { Konstanta. } \\ \beta 1, \beta 2, \beta 3 \quad & : \text { Koefisien Regresi } \\ \text { DTon } & \text { :Pajak Tangguhan } \\ & \text { perusahaan pada tahun } \\ \text { ke-t } & \text { :Proporsi property, plant } \\ \text { CIon } & \text { dan equipment terhadap } \\ & \text { total aset perusahaan i } \\ & \text { pada tahun ke-t } \\ \text { ROAon } & \text { :ROA perusahaan i pada } \\ \text { tahun ke-t } & : \text { error }\end{array}$

\section{Hasil Penelitian dan Pembahasan}

\section{Analisa Statistik Deskriptif}

\section{Statistik Deskriptif}

Analisis data ini bertujuan untuk mengetahui Deferred Tax, Capital Intensity dan ROA pada industri sub sektor pertambangan batubara yang tercatat di Bursa Efek Indonesia tahun 2016-2019. Pada tabel dibawah ini menunjukkan hasil statistik deskriptif pada ketiga variabel tersebut.

\section{Tabel 1}

\section{Statistik Deskriptif}

\begin{tabular}{lccccc}
\hline \multicolumn{5}{c}{ Descriptive Statistics } \\
& N & Min & Max & Mean & Std.Dev \\
\hline ROA & 38 & .004 & .290 & .116 & .075 \\
CAIN & 38 & .182 & 1.953 & .691 & .412 \\
DTA & 38 & -.522 & 1.328 & .144 & .438 \\
ETR & 38 & .0582 & .575 & .307 & .087 \\
$\begin{array}{l}\text { Valid N } \\
\text { (listwis }\end{array}$ & 38 & & & & \\
e) & & & & & \\
\end{tabular}

Sumber: Data yang diolah, 2021
Melalui hasil uji statistik deskriptif dalam tabel di atas ditampilkan volume data setiap variabel yang diuji sebanyak 38 perusahaan. Nilai minimum mewakili nilai terkecil, pada nilai maksimum menggambarkan nilai terbesar, nilai rata-rata menggambarkan rata-rata setiap variabel. Simpangan baku mewakili data statistik dipakai untuk mengklasifikasikan bagaimana data dalam sampel didistribusikan serta kedekatan titik data dengan nilai sampel. Variabel Return on Asset (ROA) tertulis nilai minimumnya sebesar 0,00 dan nilai maksimumnya sebesar 0,29 dengan artian memiliki nilai mean sebesar 0,1160 dan hasil statistik deskriptif ini menunjukkan ROA 11,60\% diatas standar 5\% maka perusahaan sub sektor pertambangan batubara ini memiliki kondisi keuangan yang baik yaitu diatas standar. Terkait Capital Intensity terdapat nilai minimum 0,18 dan maksimum 1,95 dengan rata-rata 0,6906. Terkait Deferred Tax tercatat nilai minimum $-0,52$ serta maksimum 1,32 dengan nilai rata-rata 0.1436. Dan untuk agresivitas pajak rasio ETR mampunyai nilai minimum 0,05 dan maksimum 0,57 dengan rata-rata 0,3070 maka dilihat dari rata-rata perusahaan sub sektor pertambangan batu bara memilki tingkat pembayaran pajak diatas $25 \%$ pajak badan yang berlaku di Indonesia. Maka dari itu secara garis besar perusahan sub sektor pertambangan batubara dalam penelitian ini rendah dalam tingkat penghindaran pajak serta memiliki kondisi keuangan yang baik.

\section{Koefisien Determinasi}

Tabel 2

Koefisien Determinasi



Sumber : Data yang diolah 2021 
Hasil uji koefisien determinasi diketahui nilai R-square 0,264. Dimana hasil tersebut menunjukkan korelasi antar variabel capital intensity, deferred tax asset, return on asset terhadap variabel agresivitas pajak rendah karena nilai $\mathrm{R}$ hanya 0,264 cukup jauh daripada angka 1 . Sedangkan pada adjusted $r$-square sebesar 0,244 atau 24,4\% yang menggambarkan pengaruh variabel independen capital intensity, deferred tax asset, return on asset atas agresivitas pajak dengan persentase $24,4 \%$ dan untuk $75,6 \%$ sisanya memperoleh pengaruh dari variabel diluar variabel independen yang saat ini sedang diteliti.

\section{Uji F (Uji Kelayakan Model)}

Tabel 3

Hasil Uji F

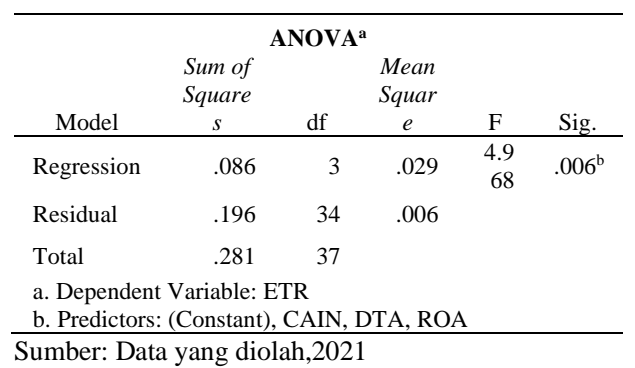

Dalam penelitian ini ditemukan uji model dengan uji signifikan $F$ menunjukkan didalam penelitian ini secara simultan adanya pengaruh signifikan antara ROA, CAIN, dan DTA terhadap ETR karena nilai signifikannya dibawah 0.05 .

\section{Uji Asumsi Klasik Autokorelasi}

\section{Tabel 4}

\section{Hasil Uji Autokolerasi}

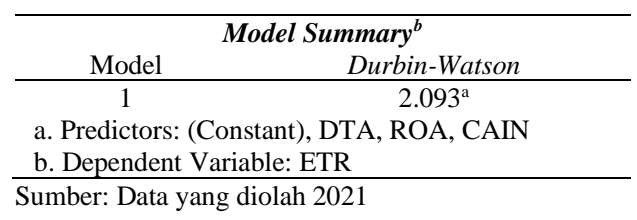

Tabel diatas menampilkan uji autokorelasi dimana tidak adanya auto korelasi pada data penelitian ini dimana nilai dw sebesar 2,093 $>$ du $(1,656)$ dan dw lebih kecil dari 4-du $(2,093<2,344)$.

\section{Uji Multikolinearitas}

Tabel 5

Hasil Uji Multikolinearitas

\begin{tabular}{|c|c|c|}
\hline \multicolumn{3}{|c|}{ Coefficients ${ }^{a}$} \\
\hline \multicolumn{3}{|c|}{ Collinearity Statistics } \\
\hline Model & Tolerance & $\mathrm{VIF}$ \\
\hline ROA & .578 & 1.729 \\
\hline CAIN & .576 & 1.737 \\
\hline DTA & .978 & 1.022 \\
\hline \multicolumn{3}{|c|}{ a. Dependent Variable: ETR } \\
\hline \multicolumn{3}{|c|}{ Sumber: Data yang diolah,2021 } \\
\hline \multicolumn{3}{|c|}{$\begin{array}{l}\text { Tabel } 6 \text { menunjukkan nilai tolerance setiap } \\
\text { variable independent, Return on Asset } \\
(0,578)>0,1 \text { dan VIF }(1,729)<10 \text {. Capital } \\
\text { Intensity }(0,576)>0.1 \text { dan nilai VIF }(1,737) \\
<10 \text {. Untuk Deferred Tax }(0.978)>0,1 \text { dan } \\
\text { VIF } 1,022<10 \text {. Dapat disimpulkan dimana } \\
\text { tidak terjadi multikolinearitas. }\end{array}$} \\
\hline
\end{tabular}

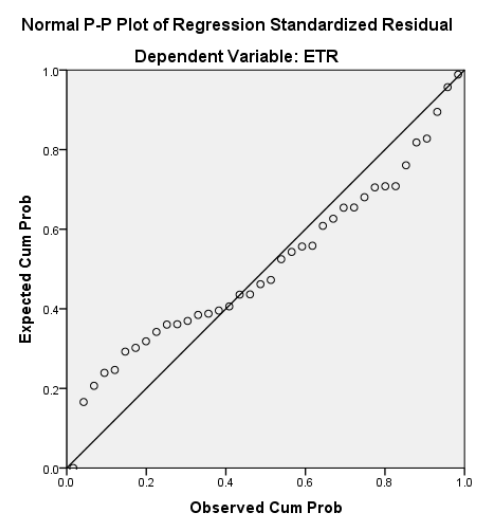

Gambar 2

Hasil P-Plot Regresi

Sumber: Data yang diolah 2021 
Gambar diatas menampilkan dimana titik plot menyebar diantara jalur diagonal maka oleh itu uji diterima dimana data terdistribusi dengan normal.



Gambar 3

Hasil Scatterplot

Sumber: Data yang diolah 2021

Gambar diatas menampilkan titik plot yang tersebar tidak membentuk suatu pola dengan itu dapat dikatakan uji diterima dimana tidak terjadi heteroskedastisitas.

\section{Analisa Regresi Berganda}

Analisa regresi linear berganda dilakukan untuk mengetahui seberapa jauh hubungan sebab akhibat antara variabel Deferred Tax, Capital Intesity, dan Return on Asset terhadap agresivitas pajak. Berikut ini merupakan hasil analisa regresi linear yang telah diolah:

Tabel 6

Hasil Analisa Regresi Berganda

\begin{tabular}{|c|c|c|c|c|c|}
\hline \multicolumn{6}{|c|}{ Coefficients $^{\mathrm{a}}$} \\
\hline \multirow[b]{2}{*}{ Model } & \multicolumn{2}{|c|}{$\begin{array}{l}\text { Unstandardzied } \\
\text { Coefficient }\end{array}$} & $\begin{array}{l}\text { Standardize } \\
\text { Coefficients }\end{array}$ & \multirow[b]{2}{*}{$\mathrm{t}$} & \multirow[b]{2}{*}{ Sig. } \\
\hline & B & $\begin{array}{l}\text { Std.Err } \\
\text { or }\end{array}$ & Beta & & \\
\hline (Constant) & .287 & .050 & & 5.794 & .000 \\
\hline DTA & .030 & .033 & .151 & .918 & .365 \\
\hline CAIN & .109 & .030 & .514 & 3.594 & .001 \\
\hline ROA & -.555 & .170 & -.477 & -3.254 & .002 \\
\hline
\end{tabular}

Sumber : Data yang diolah 2021
Melalui analisis data yang dilakukan, pola regresi yang diperoleh dari data tersebut ialah sebagai berikut:

$$
\begin{gathered}
\mathrm{ETR}=0,287-0,555 \mathrm{ROA}+0,109 \mathrm{CAIN}+ \\
0,030 \mathrm{DTA}+\mathrm{e}
\end{gathered}
$$

\section{Pengaruh DTA Terhadap ETR}

Tabel 6 menunjukkan hasil nilai signifikansi variabel deferred tax asset lebih besar dibandingkan dengan nilai probabilitas 0,05. Dari hasil ini dapat dituliskan bahwa variabel deferred tax asset tidak memiliki pengaruh yang signifikan atas ETR $(0,365>0,005)$. Dimana hasil riset ini bertolak belakang dengan riset yang dilakukan oleh Cahyani \& Kiswara (2019) dimana terdapat pengaruh signifikan antara deferred tax atas penghindaran pajak, dengan kata lain hipotesa 1 ditolak.

\section{Pengaruh CAIN terhadap ETR}

Tabel 6 menunjukkan bahwa capital intensity memiliki nilai signifikansi lebih rendah dibandingkan nilai probabilitas 0,05 dengan itu hal ini menggambarkan variabel capital intensity ini berpengaruh atas ETR $(0,001<0,05)$. Hasil ini memperoleh dukungan Rahmadi \& Suharti (2018) yang menyatakan terdapat pengaruh yang positif signifikan dari capital intensity atas agresivitas pajak. Berbeda dengan penelitian Indradi (2018) dimana tidak didapatinya pengaruh signifikan antara capital intensity dan agresivitas pajak, dengan kata lain hipotesa 2 diterima.

\section{Pengaruh ROA terhadap ETR}

Pada tabel 6 menunjukkan hasil nilai signifikansi variabel Return on Asset lebih kecil dibandingkan dengan nilai probabilitas 0,05. Dengan hasil ini dapat dinyatakan bahwa variabel Return on Asset memiliki pengaruh negatif signifikan atas ETR $(0,002<0,05)$. Dimana hasil ini tidak sejalan dengan penelitian Rina Adriani, R.,\& Fadillah (2019), dan juga penelitian 
dari Setyadi, A, \&Ayem (2019) yang menuliskan hasil penelitian ROA memiliki pengaruh positif atas ETR, dengan kata lain hipotesa 3 ditolak.

\section{Simpulan dan Saran}

\section{Simpulan}

Melalui penjabaran diatas, dapat disimpulkan secara parsial deferred tax asset tidak memiliki pengaruh signifikan atas agresivitas pajak. Deferred tax asset ialah hasil dari perbedaan waktu yang mengakibatkan koreksi positif dan hasilnya beban pajak dari sudut profitable lebih kecil daripada beban pajak dari sudut undangundang pajak. Pada penelitian ini menyimpulkan bahwa aset pajak tangguhan tidak dapat berperan langsung dalam mempengaruhi agresivitas pajak pada perusahaan pertambangan batubara, DTA harus melalui media manajemen laba dalam mempengaruhi agresivitas pajak.

Untuk variabel kedua yaitu capital intensity pada penelitian ini ditemukan memiliki pengaruh positif signifikan atas agresivitas pajak. Capital intensity berkaitan dengan aset tetap, sehingga dapat dikatakan semakin tinggi aset tetap perusahaan menjadi sebab semakin besar kemungkinan perusahaan pertambangan batubara agresif terhadap pajak, perusahaan memanfaatkan beban penyusutan dalam mengurangi kewajiban pajak perusahaan. Dapat diambil kesimpulan dalam penelitian ini capital intensity perusahaan pertambangan batubara yang tercatat di BEI periode 2016-2019 cukup tinggi, dengan kata lain proporsi aset tetap lebih tinggi dibandingkan aset lancar yang dapat di lihat dari perubahan kenaikan aset tetap setiap tahunnya dalam kurun 5 periode ini. Perusahaan batubara perlu memaksimalkan penggunaan fixed asset sampai masa manfaat dari fixed asset tersebut habis atau melebihi masa depresiasi fixed asset. Sehingga rasio capital intensity perusahaan tersebut berkurang dan tidak adanya indikasi perusahaan melakukan agresivitas pajak.

Return On Asset merupakan salah satu faktor yang memiliki pengaruh negatif signifikan terhadap agresivitas pajak. Dimana pada penelitian ini menyimpulkan pada saat persentase ROA di perusahaan pertambangan batubara tinggi akan menjadi penyebab investor tertarik untuk berinvestasi, sehingga perusahaan pertambangan batubara tidak perlu melakukan agresivitas pajak untuk mendapatkan laba yang lebih tinggi. Maka dari itu perusahaan sektor batubara perlu meningkatkan profitabilitas yang dinilai berdasarkan rasio ROA sehingga banyak investor yang ingin menanamkan modalnya pada perusahaan tersebut tanpa harus melakukan agresivitas pajak.

Secara simultan hasil daripada penelitian ini bahwa Deferred Tax Asset, Capital Intensity dan Return On Asset memiliki pengaruh yang signifikan atas agresivitas pajak. Tetapi secara parsial Deferred Tax Asset tidak memiliki pengaruh atas agresivitas pajak, Capital Intensity memiliki pengaruh positif atas agresivitas pajak dan Return On Asset memiliki pengaruh negatif terhadap agresivitas pajak.

\section{Saran}

Melalui penjabaran hasil dan kesimpulan yang sudah dijelaskan, maka terdapat beberapa hal yang dapat menjadi saran untuk perusahaan sub sektor pertambangan dan penelitian selanjutnya:

1. Pihak perusahaan pertambangan batubara disarankan dapat meminimalkan melakukan perencanaan pajak yang dapat merugikan perusahaan dan negara dimasa yang akan datang, ada baiknya pihak perusahaan melakukan tax planning dengan cara yang efektif dengan tidak melanggar peraturan perpajakan yang berlaku sehingga menghindari kerugian yang 
berdampak kepada negara dan perusahaan yang bersangkutan

2. Kepada peneliti selanjutnya dapat melakukan penelitian yang lebih mendalam dengan cara menambah atau menggunakan variabel bebas selain ROA, DTA, dan CAIN untuk melihat faktor lainnya dalam mempengaruhi perusahaan dalam melakukan agresivitas pajak, serta memperluas sektor perusahaan yang diteliti.

3. Dengan menambah variabel deffered tax asset pada perusahaan sub sektor lainnya dapat memperkaya literatur yang ada.

\section{Daftar Pustaka}

Asroni, R., Nur, E., \& Yuyetta, A. (2019). Analisis Pengaruh Tata Kelola Perusahaan Dan Karakteristik Direktur Utama Terhadap Tindakan Pajak Agresif Di Indonesia. Diponegoro Journal of Accounting, $8(2), 1-10$.

Brigham, E. F., \& Houston, J. F. (2014). Dasar-Dasar Manajemen Keuangan: Assetials Of Financial Management. In Salemba Empat.

Cahyani, M., \& Kiswara, E. (2019). Pengaruh Rasio Pajak Tangguhan, Keahlian Pajak, dan Remunerasi terhadap Penghindaran Pajak (Studi Empiris pada Perusahaan Publik .... Diponegoro Journal of Accounting.

Feryansyah, Handajani, L., \& Hermanto. (2020). Pengaruh Manajemen Laba Terhadap Agresivitas Pajak Dengan Good Corporate Governance Dan Kebijakan Dividen Sebagai Variabel Pemoderasi. Jurnal EMBA: Jurnal Riset Ekonomi, Manajemen, Bisnis Dan Akuntansi, 8(4), 140-155. https://doi.org/10.35794/emba.v8i4.3 0601

Hanafi, Mamduh M; Halim, A. (2012). Analisis Laporan Keuangan, Edisi
Keempat. Yogyakarta: UPP STIM YKPN.

Hidayat, A. T., \& Fitria, E. F. (2018). Pengaruh Capital Intensity, Inventory Intensity, Profitabilitas dan Leverage Terhadap Agresivitas Pajak. Eksis, 13(2), 157-168.

Indradi, D. (2018). Pengaruh likuiditas , capital intensity terhadap agresivitas pajak. Jurnal Akuntansi Berkelanjutan Indonesia, 1(1), 147.

Kementrian Keuangan. (2019). Laporan Keuangan Pemerintah Pusat Tahun 2019 (Audited) (p. 789). p. 789.

Lanis, R., \& Richardson, G. (2012). Corporate social responsibility and tax aggressiveness: An empirical analysis. Journal of Accounting and Public Policy. https://doi.org/10.1016/j.jaccpubpol.2 011.10 .006

Lietz, G. M. (2013). Tax Avoidance vs. Tax Aggressiveness: A Unifying Conceptual Framework. SSRN Electronic Journal. https://doi.org/10.2139/ssrn.2363828

Mulyani, S., Darminto, \& Endang N.P, M. . (2014). Pengaruh Karakteristi Perusahaan, Koneksi Politik Dan Reformasi Perpajakan Terhadap Penghindaran Pajak (Studi Pada Perusahaan Manufaktur Yang Terdaftar Di Bursa Efek Tahun 20082012). Jurnal Mahasiswa Perpajakan.

Murhadi, W. R. (2015). Analisis Laporan Keuangan: Proyeksi dan Valuasi Saham. Salemba Empat. Jurnal Ekonomi Dan Keuangan.

Putra, Y. M. (2019). Pengaruh Aset Pajak Tangguhan, Beban Pajak Tangguhan, dan Perencanaan Pajak Terhadap Manajemen Laba (Studi Empiris Pada Perusahaan Food \& Beverage Yang Terdaftar di BEI Tahun 2015-2017). Jurnal Ilmu Dan Riset Akuntansi, $8(7), 1-21$.

Putri, C. L., \& Lautania, M. F. (2016). Pengaruh Capital Intensity Ratio, 
Inventory Intensity Ratio, Ownership Structure dan Profitability Terhadap Effective Tax Rate (ETR) (Studi pada Perusahaan Manufaktur yang Terdaftar di Bursa Efek Indonesia Ta. Jurnal Ilmiah Mahasiswa Ekonomi Akuntansi (JIMEKA).

Rahmadi, Z. T., \& Suharti, E. (2018). Pengaruh Capital Intensity dan Leverage Terhadap Agresivitas Pajak pada Perusahaan Manufaktur yang Terdaftar di Bursa Efek Indonesia (BEI) Periode 2014-2018. 58-73.

Rangkuti. (2017). Analisis Swot-Teknik Membedah Kasus Bisnis. Cara Perhitungan Bobot, Rating, dan OCAI. Penerbit PT. Gramedia Pustaka Utama.

Rangkuti, F. (2013). Teknik Membedah Kasus Bisnis Analisis SWOT Cara Perhitungan Bobot, Rating, dan OCAI. In PT. Gramedia Pustaka Utama. Jakarta.

Rina Adriani,R.,\& Fadillah, A. (2019). Pengaruh Return on Asset (ROA), Current Ratio (CR), Debt To Asset Ratio (DAR), dan Capital Intensity Ratio (CIR) Terhadap Agresivitas Pajak. Jurnal Akuntansi, 14(2), 4659.

Sahala, P., \& Siahaan, O. (2020). Profitabilitas , Leverage , Capital Intensity Pengaruhnya Terhadap Agresivitas Pajak. Jurnal Penelitian Akuntansi.

Setyadi, A,\&Ayem, S. (2019). Pengaruh Profitabilitas , Ukuran Perusahaan , Komite Audit Dan Capital Intensity Terhadap Agresivitas Pajak ( Studi Pada Perusahaan Perbankan Yang Terdaftar di BEI Periode Tahun 2013. l(2), 228-241. https://doi.org/10.24964/japd.v1i1.90 5
Sudana, I. M. (2015). Manajemen Keuangan Perusahaan Teori \& Praktik. In Erlangga.

Waluyo. (2020). Akuntansi Pajak (7th ed.; E. Suharsi \& Rosidah, Eds.). Jakarta: Salemba Empat. Retrieved from https://penerbitsalemba.com/buku/030146-akuntansi-pajak-edisi-ke-7

Wijaya, D. (2017). Manajemen Keuangan Konsep dan Penerapannya (1st ed.; T. Y. Kurniawati, Ed.). Jakarta: PT. Grasindo. Retrieved from https://books.google.co.id/books?hl=e $\mathrm{n} \& 1 \mathrm{r}=\& \mathrm{id}=0 \mathrm{MRGDwAAQBAJ} \& \mathrm{oi}=\mathrm{f}$ nd\&pg=PP1\&dq=Wijaya,+D.+(2017) +Manajemen+Keuangan+Konsep+da n+Penerapannya.+Jakarta:Pt.+Grasin do\&ots=tmzdYim2Ol\&sig $=x 1 \mathrm{uLi} 5 \mathrm{rH}$ vzJfyzbAWRYbb8zY_X8\&redir_esc $=\mathrm{y} \# \mathrm{v}=$ onepage $\& \mathrm{q} \& \mathrm{f}=$ false

Xynas, L. (2011). Revenue Law Journal: The Regulatory Responses and Taxpayer Compliance. Revenue Law Journal, 20(1). Retrieved from http://epublications.bond.edu.au/rlj/vo 120/iss $1 / 2$

\section{Artikel Online}

Brama, A. (2019, Juli 04) Adaro Energy (ADRO) diduga menggelapkan pajak [Halaman Web]. Kontan.co.id. Diakses dari https://investasi.kontan.co.id/news/ adaro-energy-adro-didugamenggelapkan-pajak 